\title{
A KORONAVÍRUS-JÁRVÁNY ÉS FELVÁSÁRLÁSI LÁZ NÉHÁNY ÖSSZEFÜGGÉSÉNEK VIZSGÁLATA GYÔRBEN
}

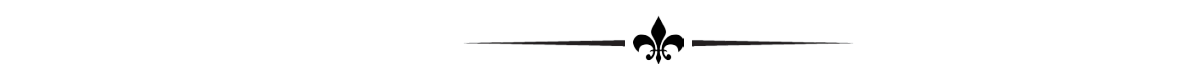

\section{INVESTIGATION OF SOME CONNECTIONS BETWEEN THE CORONAVIRUS EPIDEMIC AND “ACQUISITION FEVER” IN GYŐR}

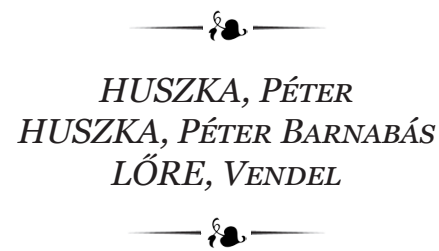

Széchenyi István Egyetem, Kautz Gyula Gazdaságtudományi Kar, Marketing és Menedzsment Tanszék (Széchenyi István University, Kautz Gyula Faculty of Economics, Department of Marketing and Management) H-9026 Győr, Egyetem tér 1. e-mail: huszkap@sze.hu

The birth of this publication was generated by the events of today. In the light of the research (and the literature data), it can be stated that the coronavirus epidemic that appeared in Hungary in the spring of 2020 caused panic shopping, and the freedom of choice (abundance of goods) was again replaced by consumer vulnerability like before the years of regime change. The analysis shows that 75 percent of those over the age of 60 , while only 62 percent of the members of the youngest age group think it is worth piling up. It is also interesting to note that the main reason for over-buying is the creation of a contingency reserve. Larger store types, mostly with a wide range of goods, were well suited for this. Also, $33,2 \%$ of respondents thought they had bought more to reduce the number of shopping trips (and thus presumably to slow down the spread of the virus).

KuLCSSZAVAK: táplálkozás, pánikfelvásárlás, egészség, koronavírus

JEL-KóDoK (JEL CODES): M31, H12

DOI: https://doi.org/10.20494/TM/7/1/7

\section{BEVEZETÉS - INTRODUCTION}

A világ fejlett országainak élelmiszer-gazdasága az elmúlt évszázadban gyökeres változásokon esett át. A világháborút követően az élelmiszeripari termelés fó feladata az volt, hogy elegendő mennyiségben biztosítson táplálékot az éhező tömegeknek. A gazdaság talpra állását követően a társadalmi jólét is fokozódni kezdett - különösen a tengerentúlon és Nyugat-Európában. Ezzel párhuzamosan egyre inkább fontossá vált az egészségmegőrzés és ezzel kapcsolatban olyan fogalmak és persze
KEYWORDS: nutrition, panic buying, health, coronavirus

termékek jelentek meg, mint például a funkcionális élelmiszerek.

A táplálkozás, az egészséges életvitel szerepének hangsúlyozása nem a XXI. század „egészségtudatos emberének” találmánya, bár tagadhatatlan, napjaink sajtóközleményei sokszor ezt sugallják. Már Hippokratész, a közismert ókori görög orvos a szervezet természetes gyógyító erejének támogatását tekintette az orvos legfontosabb feladatának. „Táplálékod legyen az orvosságod, és az orvosságod a táplálékod legyen" - fogalmazott az ókori tudós.

$\mathrm{Az}$ élelmiszerekkel kapcsolatos fogyasztói 
magatartás vizsgálata a XX. század kiemelkedően fontos kutatási területe volt és természetesen az jelenünkben is. Úgy tűnik azonban, hogy napjaink váratlan eseményei jelentősen átírhatják, illetve módosíthatják korábbi, a „nem háborús körülmények között” megalkotott modelljeinket. Például LEHOTA (2001) az élelmiszer-fogyasztást befolyásoló tényezők rendszerezése során sem vette figyelembe a napjainkban különösen jellemző pánikbevásárlás lehetőségét. 2020 tavaszán ugyanis hazánkban is megjelent a koronavírus-járvány. Mikrobiológiailag a Coronaviridae család foglalja magába a Koronavírus nemzetséget. Elnevezését onnan kapta, hogy a vírusrészecske a felszínén lévő nyúlványokkal a nap koronájára emlékeztet (BELÁK et al., 1983). A vírus megjelenése nem csak hazánk, de az egész világ életét átrajzolja és hatással van a vásárlási és fogyasztási szokásainkra is. Az Egészségügyi Világszervezet (WHO, World Health Organization) meghatározása szerint az egészség az ember testi, lelki és szociális jólétét jelenti, és nem csupán a betegség vagy fogyatékosság hiányát.

Az egészség csak akkor fenntartható, ha annak dimenziói kielégítő szinten múködnek, úgy, mint a biológiai egészség, amely magában foglalja testünk megfelelő múködését, a lelki egészség, ami világnézetünk, erkölcsi alapelveink, tudatunk nyugalmát, valamint a belső békét jeleni. Nem kevésbé fontos a mentális egészség, a tiszta, racionális és logikus gondolkodás, az érzelmi egészség - az érzések felismerése, megélése és kifejezése - valamint a szociális egészség, ami többek között az embertársainkkal megfelelő kapcsolatok kialakítását foglalja magában (KOMÁNYI, 2014).

$\mathrm{Az}$ egészség nem csupán cél, hanem egy erőforrás is, melyet a mindennapokban használunk. A jó egészségügyi állapot ugyanis nem csak az egyén érdeke, hanem a társadalomé is, mivel a „dolgozó ember” mint munkaerő a termelési és érték-előállítási (transzformációs) folyamat fontos eleme. Így egészségügyi állapota és egészségügyi állapotának megtartása a társadalomnak is alapvető érdeke. A legfontosabb cél ezért az egyes emberek és közösségek testi és lelki jólétének, egészségének lehetőség szerinti, minél hosszabb távú biztosítása. A 2020 tavaszán hazánkban (is) lezajló események még egy laikus számára is nyilvánvalóvá tet- ték azt, hogy az egészség és a gazdaság között szoros összefüggés van. Napjaink világjárványa következtében számos munkahely megszűnt, a beszállítói lánc megszakadása csak erősíti ezt a folyamatot, a kormányzati intézkedések - amelyet a vírus terjedésének lassítása érdekében tettek - pedig számos ágazat (turizmus, vendéglátás, és persze számos kiskereskedelmi tevékenység) munkáját és foglalkoztatottsági tevékenységét tette nehézzé. Mindezek következtében nőtt a munkanélküliség, aminek negatív gazdasági hatásai elvitathatatlanok.

Jelen publikáció megszületését napjaink eseményei generálták. A járványt övező felvásárlási láz ugyanis felkeltette érdeklődésünk - és jelen publikációban (hangsúlyozottan egy feltáró, gondolatébresztő publikáció keretében) néhány ezzel kapcsolatos fogyasztói szokásra fókuszáló kérdés megválaszolására törekedtünk.

Természetesen a bevezetésre került kormányzati intézkedések - és a vásárlásokat övező sokszor frusztrált légkör - megadja a kutatás korlátait is. Mindezeket az „Anyag és módszer” részben részletesen bemutatjuk. A kutatás nem törekedett reprezentativitásra, de a bemutatott eredmények elgondolkodásra ösztönözhetnek bennünket.

\section{SZAKIRODALMI ÖSSZEFOGLALÓ}

\section{- TheORETICAL BACKGROUND}

\subsection{Az egészség és az egészségügyi állapot néhány összefüggése - Some Issues on Health and Health Condition}

Köztudomású, hogy világviszonylatban évente közel 10 millió ember veszti el életét, mert nem jut megfelelő mennyiségü és minőségü ivóvízhez és 2020 áprilisában közel 850 millió ember tekinthető alultápláltnak. A feltörekvő piacok egy része ugyanis nem jut elegendő táplálékhoz, ugyanekkor a másik fele civilizációs betegségekkel (magas vérnyomás, túlsúly stb.) küzd. Mi sem bizonyítja ezt jobban, mint, hogy a fenti időpontban több mint 1,6 milliárd ember tekinthető túlsúlyosnak (WORLDOMETERS, 2020a). Napjaink világméretű járványa az előzőektől eltérően teljesen másfajta megbetegedés és kezelése is más módon kell, 
hogy megvalósuljon. A kialakult vírusfertőzés ugyanis nem a jóléti államok megbetegedése - mint például a túlsúly -, de nem is a fejlődő országok sokszor áldatlan körülményei miatt fellépő megbetegedés.

2020. január elején (hivatalosan is) feltünt Kínában egy addig ismeretlen koronavírus okozta felső légúti megbetegedés a 12 millió lakosú Vuhanban. Az addig ismeretlen, így a szervezet immunrendszere által sem felismerhető megbetegedés (amely cseppfertőzéssel is terjed) gyorsan világméretű járványt okozott. A következő hónap végére már csaknem ötven országban jelent meg az említett vírus és okozott súlyos megbetegedéseket.

Jelen tanulmányban csupán utalni szeretnénk arra, hogy 2020. húsvét hétfőjén (a tanulmány leadása miatt, a statisztikai adatokat „le kellett zárni” - még akkor is, ha tudjuk, hogy a cikk megjelenésekor ezek az adatok már nem fogják tükrözni a valóságot - hiszen a pandémia exponenciálisan terjed), a világon 1923937 ember tekinthető igazoltan új koronavírussal fertőzöttnek. 452402 fő tekinthető fertőzésből kigyógyultnak és sajnálatosan 119 730-an elhunytak a fertőzés következtében (WORLDOMETERS, 2020b). Hazánkban ezen a napon 1512 fö volt igazoltan fertőzött és 122en hunytak el a betegség következtében.

Mint arról már az előzőekben is szóltunk, a világjárvány következtében számos munkahely megszűnt, a beszállítói lánc megszakadása pedig számos ágazat (turizmus, vendéglátás, és persze számos (ipari) kiskereskedelmi tevékenység) munkáját és foglalkoztatottsági tevékenységét tette nehézzé. Mindezek következtében nőtt a munkanélküliség, aminek negatív gazdasági hatásai elvitathatatlanok. Elegendő csak arra utalnunk itt, hogy az előzőekben említett napon az USA-ban már 16 millió munkahely szűnt meg a járvány következtében. Hazánkban pedig április elejére közel 55 ezer ember munkája szűnt meg hasonló okok miatt.

A KSH honlapján publikált foglalkoztatottsági és gazdasági adatok azt mutatják, hogy az elbocsátási hullám áprilisban felerősödött és munkanélküliségi ráta 6,5 százalékot ért el. $\mathrm{Az}$ adatok azt is mutatják, hogy április végére közel 140 ezret ért el a COVID 19 vírus miatt elbocsátottak száma. A gazdaság „gyengélke- dését” az is mutatja, hogy a GDP volumenváltozása az előző év azonos negyedévéhez képest - a szezonális naptárhatással kiigazítva - csupán két százalékot ért el. A KSH adataiból az is kiderült, hogy 2020 áprilisában a távmunkában vagy home office-ban dolgozók aránya több mint tízszerese az egy évvel korábbinak és 16,7\%-os arányt ért el (KSH, 2020b).

Kedvező hatású lehet persze, hogy Kína 2020. március 12-én bejelentette, hogy az országban véget ért a koronavírus-járvány. Sajnálatos módon ott 80 ezren fertőződtek, és több mint 3 ezren haltak meg, de az élet - jelenleg legalábbis úgy tűnik - kezd visszatérni a rendes kerékvágásba, és ha lassan is, a gazdaság fejlődésnek indult.

2020. június elején a járvány Európában így hazánkban is lecsengeni látszódik és a vírus terjedését csökkenteni igyekvő veszélyhelyzet is megszüntetése kerül június közepén. A megjelenés és a lektorálási folyamat „elhúzódása miatt" ezért szükségesnek éreztük néhány „naprakész adat” szerepeltetését is. A világon 2020. június 10.-én 7325401 ember tekinthető igazoltan új koronavírussal fertőzöttnek. 3 605284 fő tekinthető fertőzésből kigyógyultnak és sajnálatosan 413 749-en elhunytak a fertőzés következtében (WORLDOMETERS, 2020c). Hazánkban ezen a napon 4017 fő volt igazoltan fertőzött és 550-en hunytak el a betegség következtében és 2324-en gyógyultak meg a betegségből.

Mindezek a tények rávilágítanak az egészségmagatartás fontosságára. Hiszen a vírus terjedését nagymértékben lassítani és megakadályozni lehetett a személyi higiénia megtartásával, a betegség tüneteinek figyelésével, szükség esetén házi karanténba vonulással, és a speciális helyzet miatt a világhálón való tájékozódás is sok segítséget adhatott (1. ábra). $\mathrm{Az}$ egészségmagatartás rendszere persze egy rugalmas rendszer, hiszen napjainkban az információs, kommunikációs és technikai forradalom és annak széleskörü elterjedése korszakában például az információk hitelessége (a vírusról és annak terjedéséről), a gyors alkalmazkodás képessége is befolyásolja, befolyásolhatja egészségünket. Az egészségmagatartás legfontosabb elemeit az 1. ábra szemlélteti. 


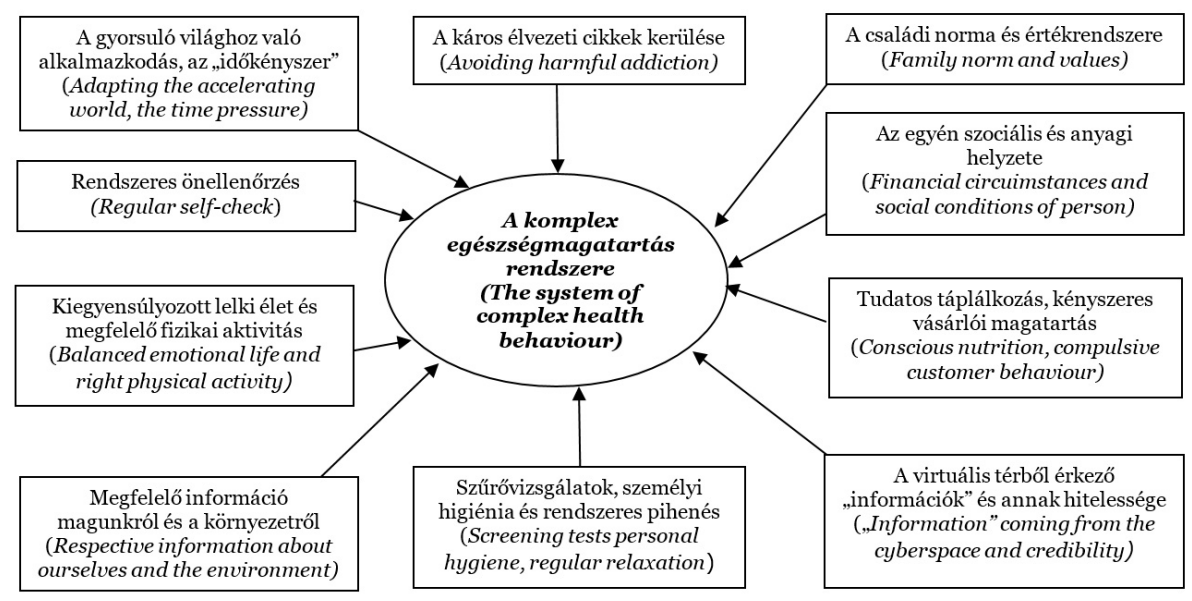

1. ÁBRA

\section{Az egészségmagatartás komplex rendszere \\ (The Complex System of Health-behaviour)}

FIG. 1

Forrás (Source): HARRIS és GUTEN (1979), illetve HUSZKA, 2012 alapján saját szerkesztés (Own construction based on HARRIS and GUTEN (1979), HUSZKA, 2012)

\subsection{A szükséglettől a vásárlási lázig - From Needs to Shopping Fever}

A szükséglet bizonyos alapvető (biológiai vagy pszichológiai) kielégítetlenség esetén jelentkező hiányérzet. A kielégítő élet utáni vágy, amely cselekvést vált ki annak megszüntetésére. A szükséglet kielégíthető vásárlás, birtoklás, termékhasználat vagy szolgáltatás igénybevételével. Ezeket a gazdasági javakon alapuló kívánságokat nevezzük szükségletnek. A szükségletet belső és külső inger is kiválthatja, belső inger (hatás) esetén az egyén valamely alapszükséglete - éhség, szomjúság - elér egy bizonyos határt és cselekvést vált ki (KOTLER and KELLER, 2012; HUSZKA, 2015).

Ezen szükségletek a Maslow piramis első szintjén jelennek meg. Külső inger (hatás) lehet a tömegkommunikáció, reklám stb., de egy kedvezőtlen hír is, mint jelen esetben a koronavírustól (COVID-19) vagy annak következményeitől való félelem.

Ez utóbbinak lehettünk tanúi 2020 tavaszán mind hazánkban, mind világviszonylatban. Ez a félelem - talán legjobban attól, hogy bezárnak a boltok, megáll a termelés az élelmiszergazdaságban - váltotta ki az immáron háborús körülményeket idéző (élelmiszer) felvásárlási hullámot. A kutatás későbbi eredmé- nyeinek tükrében itt szeretnénk jelezni, hogy LEHOTA (2001) „Az élelmiszer-fogyasztást befolyásoló tényezők rendszerelemzése" sem számol napjaink pánik és felhalmozási bevásárlásaival, ezért ezzel a modellt mindenképpen bővíteni szükséges.

A hazai és nemzetközi adatok is alátámasztják azt, hogy a koronavírus globális elterjedése miatt egyre több ember tett komolyabb előkészületeket, - egy nagyobb járványtól tartva - növelte vásárlásait. Hazánkban, 2020 februárjában az élelmiszer- és élelmiszer jellegű vegyes kiskereskedelmi üzletekben 10,7, a nem élelmiszer-kiskereskedelmi üzletekben 11,3 százalékkal emelkedett az értékesítés naptárhatástól megtisztított volumene. A már február végén kezdetét vevő felvásárlási láz a KSH becslése szerint a teljes kiskereskedelmi forgalom 11 százalékos bővüléséből 5,7 százalékpontot magyaráz (KSH, 2020a). A március 9-15. közötti kiskereskedelmi adatok elemzése szerint egyértelmű összefüggés rajzolódik ki az kormányzati lépések és a vásárlási adatok között - derül ki a Nielsen országos reprezentatív felméréséből. A felmérés szerint a kiskereskedelmi láncok esetében közel 50 százalékos értékbeli emelkedés volt tapasztalható az előző év azonos időszakához képest (FORBES, 2020).

Ez a jelenség az egész világon szétterjedt, 
akár maga a vírus. Szingapúrban például a közösségi médiát elárasztották a fotók az üzletek üres polcairól, és az emberekről, amint hatalmas mennyiségekben vásárolnak háztartási termékeket. Észak-Olaszország számos térségében is üres polcokkal találkozhattak a vevők, ami csak erősítette az áruhiánytól való félelmet (PENZCENTRUM, 2020). A pánikvásárlás nyomán számos országban a szupermarketek polcai kiürültek és hiánycikké vált a betegségek idején viselt arcmaszk is, aminek viselését sok országban - már ekkor - kötelezővé tették a közterületeken (INFOSTART, 2020). Németországban lisztet, konzerveket vásároltak fel leginkább, de a vécépapír iránti kereslet is jelentősen megnőtt (STUTTGARTER-ZEITUNG, 2020). Franciaországban a vörösbor fogyott el. A hollandoknál akkor tört ki az igazi pánik, amikor kiderült, hogy a marihuánát legálisan árusító coffeeshopok is be fognak zárni (SOKSZÍNƯVIDÉK, 2020; TRENDFM, 2020). Új-Zélandon pedig a rizs iránti kereslet volt a legkiemelkedőbb, de a gyógyszerek és étrend-kiegészítők forgalma is jelentősen megnőtt (SHAW, 2020).

Mind hazai, mind világviszonylatban sokan választják az online vásárlást a helyzetre való tekintettel (INDEX, 2020). A vásárlások például Németországban is eltolódtak az online vásárlás irányába (KSTA, 2020). Ahogyan a COVID-19 világjárvány az Egyesült Államokban elterjedt, (az Apptopia App Store hírszerző cég adatai szerint) megugrott az online bevásárlós applikációk letöltéseinek száma is. Öszszehasonlítva a februári és a 2020. március 15-i, átlagos napi letöltéseket az Instacart, a Walmart Grocery és a Shipt napi letöltései 218\%-kal, 160\%-kal és 124\%-kal növekedtek (2. ábra).

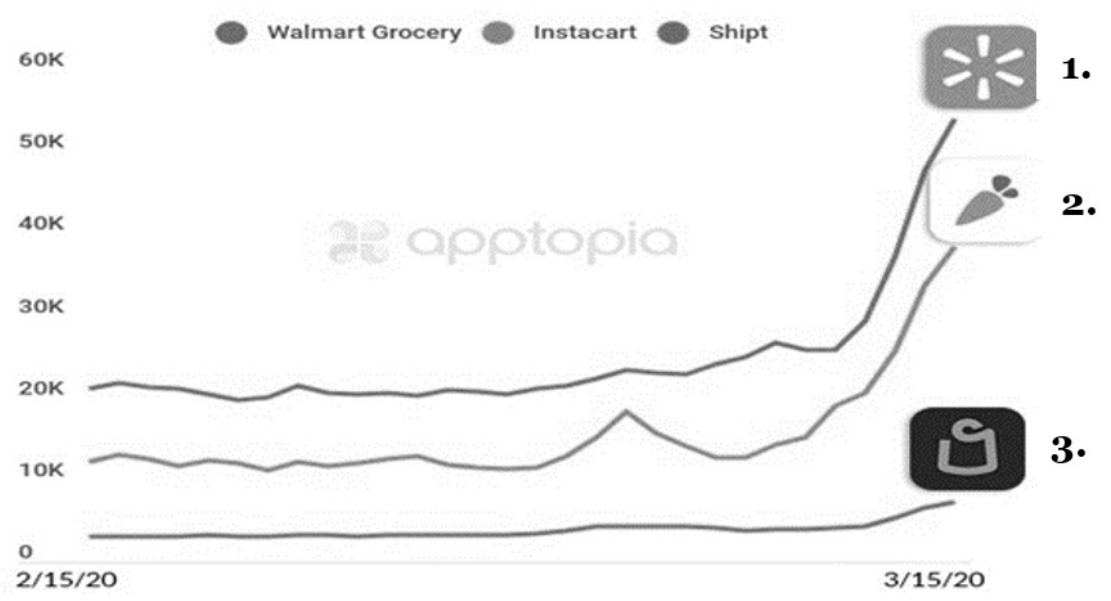

2. ÁBRA $2 / 15 / 20$

$3 / 15 / 20$

FIG. 2

A szupermarketek online bevásárlási applikációi letöltéseinek növekedése az USA-ban (Daily Downloads of Online Shopping Applications)

Forrás (Source): PEREZ (2020)

Megjegyzés (Notes): 1. Walmart Grocery; 2. Instacart; 3. Shipt

\section{ANYAg ÉS MÓDSZer - MATERIAL AND METHOD}

A kutatás lebonyolítására 2020. március 1315-i hétvégén került sor (ekkor jelentette be a Miniszterelnök az iskolák bezárását). A kutatás során (a teljesség igénye nélkül) a következő kérdésekre kerestük a választ: Arra kértük a vá- laszolókat, becsüljék meg, hogy 2020. március 13-15 közötti hétvégén mennyivel vásároltak több élelmiszert, mint egy szokásos hétvégén. Körülbelül mekkora mennyiséget $(\mathrm{kg} / \mathrm{liter} / \mathrm{db}$ stb.) vásárolt az adott termékból. Hol, milyen üzletekben vásárolt, mit gondol a kialakult vásárlási lázról?

A kutatás lebonyolítása során olyan embereket kérdeztünk meg, akik ezen a hétvégén 
vásárlásokat végeztek. A hirtelen jött kutatási ötlet miatt kezdetben a felmérés eredményeit „jegyzeteléses módszerrel” valósítottuk meg, azaz a pénteki napon a bevásárlóközpontokban és azok parkolójában (jelen cikk egyik szerzője) személyesen kérdezte meg a vásárlókat vásárlási szokásaikról - azt hogy milyen termékek találhatók a válaszadók bevásárló kocsijában -, és azokat lejegyzetelte.

A felfokozott hangulat következtében a válaszok nehezen gyültek és félő volt, hogy nem sikerül megfelelő számú válaszadót megkérdezni. A szombati és vasárnapi napokon ezért további két kérdezőbiztos került bevonásra, akik segítségével - az előző este összeállított és kinyomtatott kérdéssor alapján - sikerült kutatásunkat kiterjeszteni és megfelelő számú válaszadót elérnünk. A kérdéssor 27 alapélelmiszert sorolt fel, de rákérdeztünk a tisztító- és fertőtlenítőszerek és egyéb termékek, mint például az élesztő vásárlására is. A kérdezőbiztosok bevonásával lehetőség volt immáron már nem csak a bevásárlóközpontokban (Tesco, Metro stb.), hanem kisebb élelmiszerboltokban (pl. Coop) és élelmiszert is árusító - nagyobb alapterületü -üzletekben (pl. Lidl, Aldi) és azok parkolójában is elvégezni a személyes megkérdezést.

A felmérés nem törekedett és nem is törekedhetett reprezentativitásra - aki ezekben a napokban volt bevásárolni, jól láthatta a felfokozott hangulatot - de a bemutatott eredmények elgondolkodásra ösztönözhetnek bennünket. A kutatás további korlátja, hogy a felhasznált irodalmi források elérhetősége is korlátozott, így döntően az internet segítségével elérhető publikációk kerültek feldolgozásra.

A fent említett módszerekkel 235 győri vásárlás került az elemzés tárgykörébe. A cikkben bemutatott elemzések és adatok a 235 válaszadó véleményét tükrözi, de a bemutatott eredmények - mint azt korábbiakban jeleztük, elgondolkodtatóak. A válaszadók 47,2 százaléka férfi, 52,8 százaléka nő volt, 16,4 százalékuk 60 évnél idősebb, míg 25,1 százalékuk a 15-29 éves korosztály tagjai közé tartoztak. A megkérdezettek 28,1 százaléka volt felsőfokú végzettségü és 37 százalékuk érettségivel rendelkezett.

Az adatok kiértékelése az SPSS matematikai-statisztikai programcsomag segítségével történt.

\section{EREDMÉNYEK - RESULTS}

\subsection{A vásárlási döntéseinek vizsgálata - Analysis of Buying Decisions}

A rendszerváltást követően a gazdaság szinte minden területén változások sorozata indult el. Az élelmiszeripar és a kereskedelem is ezen rendkívül gyorsan fejlődő és átalakuló területek közé tartozott. A piacgazdaság kiépülésével párhuzamosan hatalmas és bőséges áruválaszték alakult ki az üzletek polcain és megjelentek az áruházláncok, a monumentális bevásárlóközpontok, hiper- és szupermarketek. A bőséges áruválaszték a választás szabadságát adta a fogyasztóknak (árubőség). A 2020 tavaszán hazánkban is megjelenő koronavírus-járvány azonban - mint ahogy az előzőekben (és a kutatás eredményeiben is) bemutatásra került pánikvásárlást okozott, és a választás szabadságát újra - a rendszerváltás éveit megelőző - fogyasztói kiszolgáltatottság váltotta fel. Az előzőekben megfogalmazott - hipotézisnek is tekinthető - megállapításunkra tekintettel a következőkben a fogyasztók vásárlási döntéseit vizsgáltuk. A vizsgálat során először arra kerestük a választ, hogy a fogyasztók - a vizsgált időszakban - vásárlásaikat milyen üzlettípusokban bonyolították le, és mit gondoltak a bevásárlások szükségszerüségéről. $\mathrm{Az}$ 1. táblázatban azt mutatjuk be, hogy a különböző bolttípusok milyen arányban részesednek a vásárlásban. A táblázat adatai azt jelzik, hogy a hazai élelmiszer-kereskedelemben legnagyobb súllyal a hiper- és szupermarketek, a nagyobb ABC-k és élelmiszert is árusító diszkontüzletek (pl. Lidl) részesednek. A két bolttípus együttes részesedése a forgalomból meghatározó (85,5\%). A kisebb élelmiszerboltokban és a piacokon való vásárlás a vizsgált hétvégén elenyésző volt. A táblázat adatai és a késóbbiekben bemutatásra kerülő eredmények rávilágítanak arra is, hogy ebben az időszakban sokan tartalékkészleteket halmoztak fel a különböző termékekből. A széles áruválasztékkal rendelkező nagyobb bolttípusok erre messzemenőkig alkalmasak voltak. A táblázatból leolvasható az is, hogy az idősebb korosztály tagjai körében is kedveltek voltak ezek a boltok. Személyes megfigyeléses vizsgálatunk is azt támasztja alá, hogy ezekben a napokban a piacokon sem ta- 
pasztaltunk már a szombatonkénti nyugdíjas vásárlási rohamot.

A hiper- és szupermarketekben vásárlók között a nemek tekintetében minimálisan, de a nők vezetnek. A korcsoportok vonatkozásában a 30-39 éves korosztály körében a legkedveltebb bevásárlási hely a hiper- vagy szupermarket $(78,9 \%)$, de ezen a hétvégén a nyugdíjasok valamivel több, mint 40\%-a s vásárolt itt.

Miután bemutatásra került a különböző bolttípusok részesedése a vásárlásokból, arra keressük a választ, hogy a vevő a vásárlásait mennyire készíti elő, illetve van-e összefüggés a „bespájzolás” és a vásárlás előkészítése között. A vevőt ugyanis vásárlásai során számos impulzus éri, ami befolyásolhatja magát a vásárlást, elbizonytalaníthatja a vásárlót, ugyanakkor vásárlásra is ösztönözhet. A vásárlók egy része meghatározott céllal érkezik az üzletekbe, mások viszont csak a vásárlás helyén döntik el, hogy milyen terméket tegyenek kosarukba. Egy felmérés szerint a vásárlói döntések jelentős része a boltokban születik meg, de a vásárlók kb. 23\%-a nem változtat eredeti elképzelésein (MAI PIAC, 2000).

A 2. táblázat adatai azt mutatják, hogy a vásárlását tekintve csupán $6 \%$ azok aránya, akik kizárólag a vásárlás helyén döntik el, hogy megvegyék-e az adott terméket vagy sem. Azt gondoljuk ezen a hétvégén ez az alacsony arány nem meglepő, alátámasztja azt a hipotézisünket, miszerint az emberek „félve valamitől” megtervezik vásárlásaikat. Azaz nem elrohannak a boltba és vásárlásba kezdenek, hanem azt megtervezik, amit mutat az is, hogy a válaszadók közel 47 százaléka határozott céllal érkezett a boltba és már otthonában eldöntötte, hogy mely termékeket fogja megvásárolni.

TABLE 1

Bolttípusok részesedése a vásárlásban az életkor függvényében, \% (Proportion of Various Shop Types in Purchasing, Analysed by Age Groups, \%)

\begin{tabular}{|c|c|c|c|c|}
\hline \multirow[b]{2}{*}{ Bolttípusok (Types of shops) } & \multicolumn{4}{|c|}{ Életkor (Age) } \\
\hline & $\begin{array}{c}\text { 15-29 éves } \\
\text { (15-29 years } \\
\text { old) }\end{array}$ & $\begin{array}{c}\text { 30-39 éves } \\
\text { (30-39 } \\
\text { years old) }\end{array}$ & $\begin{array}{c}40-59 \text { éves } \\
(40-59 \\
\text { years old) }\end{array}$ & $\begin{array}{c}60 \text { felett } \\
\text { (over the } \\
\text { age of } 60 \text { ) }\end{array}$ \\
\hline $\begin{array}{l}\text { Szuper- és hipermarket (Super-and hypermarket) } \\
(\mathrm{N}=148)\end{array}$ & 24,3 & 20,3 & 44,6 & 10,8 \\
\hline $\begin{array}{l}\text { ABC és élelmiszert is árusító diszkontüzletek } \\
\text { (ABC and grocery store) (pl. Lidl) }(\mathrm{N}=47)\end{array}$ & 27,7 & 6,4 & 38,3 & 27,7 \\
\hline Kisebb élelmiszerbolt (Grocery) $(\mathrm{N}=29$ ) & 20,7 & 17,2 & 34,5 & 27,6 \\
\hline $\begin{array}{l}\text { Közvetlenül a termelőtól (Directly from the producer) } \\
(\mathrm{N}=2)\end{array}$ & 50,0 & $\mathrm{O}, \mathrm{O}$ & 50,0 & $\mathrm{O}, \mathrm{O}$ \\
\hline Piacon (Marketplace) $(\mathrm{N}=2)$ & 50,0 & 0,0 & 50,0 & 0,0 \\
\hline
\end{tabular}

Forrás (Source): Saját kutatás (Own research) N=228

A vásárlások előkészítése és a felvásárlási szándék kapcsolata, \% (Relationship between Purchasing Preparation and Accumulation, \%)

\begin{tabular}{ccccc}
\hline $\begin{array}{c}\text { Mit gondol } \\
\text { érdemes } \\
\text { „bespájzolni” az } \\
\text { élelmiszerekból? } \\
\begin{array}{c}\text { (Is It Worth } \\
\text { Accumulating } \\
\text { Foods?) }\end{array}\end{array}$ & $\begin{array}{c}\text { Részben elöre, } \\
\text { részben a vásárlás } \\
\text { helyén dönt (Partially } \\
\text { decide before, } \\
\text { partially during the } \\
\text { shopping) }\end{array}$ & $\begin{array}{c}\text { Elöre eldönti } \\
\text { és listát készít } \\
\text { (Decide before } \\
\text { shopping and } \\
\text { make a list) }\end{array}$ & $\begin{array}{c}\text { Elóre eldönti, } \\
\text { de nem készít } \\
\text { listát (Decide } \\
\text { before shopping, } \\
\text { but have no } \\
\text { shoppping list) }\end{array}$ & $\begin{array}{c}\text { Kizárólag } \\
\text { a vásárlás } \\
\text { helyén dönt } \\
\text { (Decide } \\
\text { during the } \\
\text { shopping) }\end{array}$ \\
\hline Igen (Yes) (N=136) & 46,3 & 35,3 & 12,5 & 5,9 \\
\hline Nem (No) (N=88) & 43,2 & 33,0 & 11,4 & 12,5 \\
\hline $\begin{array}{l}\text { Nem tudom (Do not } \\
\text { know) (N=1) }\end{array}$ & 0,0 & 0,0 & 100,0 & 0,0 \\
\hline
\end{tabular}

Forrás (Source): Saját kutatás (Own research) N=225 
Magasnak mondható és 46,3\%-ot ér el azok aránya, akik részben hagyják magukat befolyásolni vásárlásaik során. Ôket a boltban ért kedvező és esetleg kedvezőtlen hatások megerősíthetik, vagy éppen eltántoríthatják vásárlási szándékuktól. Ôket vásárlásaik során „isis" pozíció jellemzi.

A háttérváltozók vizsgálata során a vásárlások előkészítése és a felvásárlási szándék kapcsolata is látható a 2. táblázatban. Általánosságban megállapítható, hogy a válaszadók 60,4\%-a szerint érdemes felvásárolni. Az életkor szerinti elemzés azt mutatja, hogy a 60 év felettiek 75 százaléka vélekedik így, míg a legfiatalabb korcsoport tagjai közül csak 62 százalék gondolja azt, hogy érdemes „bespájzolni”. Felvetődhet a kérdés, hogy mi motiválja az embereket a felhalmozásra. A 3. táblázat ezt szemlélteti.

A további elemzés ismételten alátámasztja azon hipotézisünket, miszerint a vizsgált hét- végén a válaszadók többsége (85\%) bizonyos termékekből többet vásárolt. Csupán a megkérdezettek 15 százaléka jelezte, hogy ez rájuk nem igaz. A 3. táblázatban olvasható összefüggés a mintában trendszerúen jelentkezik, de az alapsokaságra nem szignifikáns $(\chi 2(5)=4,061$, $\mathrm{p}=0,541)$. A vizsgálatba bevont személyek 16,4 százaléka 60 évnél idősebb volt. Esetükben $89,2 \%$ úgy vélekedett, hogy növelte vásárlásait. A pólus másik végét a 15-29 éves korosztály jelenti, ahol 25 százalék azok aránya, akik nem vásároltak többet a különböző termékekből ezen a hétvégén.

Érdekes azt is megfigyelnünk, hogy a többletvásárlás legfőbb kiváltó indoka a bevásárlási alkalmak csökkentése és vele együtt a biztonsági tartalék képzése, hogy „legyen otthon”, mint sokan azt a nyitott kérdésekre adott válaszoknál megjegyezték. A hatvan évnél idősebbek körében egyértelmúen a bevásárlási alkalmak csökkentése a legfőbb motiváló tényező.

3. TÁBLÁZAT

A vásárlások motivációi és az adatokat szolgáltató személyek életkora közötti kapcsolat (Relationship between Purchasing Motivation and Age of Respondents)

Miért vásárol többet (Why Did You Buy More)

\begin{tabular}{|c|c|c|c|c|c|c|}
\hline \multirow[b]{2}{*}{$\begin{array}{l}\text { Korcsoport } \\
\text { (Age gorup) }\end{array}$} & \multicolumn{6}{|c|}{ Miért vásárol többet (Why Did You Buy More) } \\
\hline & $\begin{array}{c}\text { Biztonsági } \\
\text { tartalék/ } \\
\text { készlet } \\
\text { (Safety } \\
\text { stock) }\end{array}$ & $\begin{array}{c}\text { Esetleges } \\
\text { hiány } \\
\text { (Possible } \\
\text { shortage) }\end{array}$ & $\begin{array}{c}\text { Késóbb is } \\
\text { jó a termék } \\
\text { (Products } \\
\text { can be used } \\
\text { later) }\end{array}$ & $\begin{array}{c}\text { A } \\
\text { bevásárlási } \\
\text { alkalmak } \\
\text { csökkentése } \\
\text { (To } \\
\text { reduce the } \\
\text { number of } \\
\text { shoppings) }\end{array}$ & $\begin{array}{c}\text { Kijárási } \\
\text { tilalom lesz } \\
\text { (Possible } \\
\text { curfew) }\end{array}$ & $\begin{array}{c}\text { Nem } \\
\text { vásárolt } \\
\text { többet (Did } \\
\text { not buy } \\
\text { more) }\end{array}$ \\
\hline $\begin{array}{l}\text { 6o év alatti } \\
\text { (Under } \\
60 \text { years) } \\
(\mathrm{N}=189)\end{array}$ & 23,8 & 15,9 & 7,4 & 31,2 & 5,8 & 15,9 \\
\hline $\begin{array}{l}60 \text { év feletti } \\
\text { (Over } 60 \\
\text { years) }(\mathrm{N}=37)\end{array}$ & 18,9 & 10,8 & 5,4 & 43,2 & 10,8 & 10,8 \\
\hline
\end{tabular}

Forrás (Source): Saját kutatás (Own research) N=226

\subsection{A vásárlási döntések változásának termékcsoportonkénti vizsgálata - Analysis of Buying Decisions in Product Categories}

A vizsgálat folytatásaként arra a kérdésre is kerestük a választ (termékcsoportonként), hogy az adott hétvégén mekkora mennyiség- ben vásároltak a válaszadók és ez a vásárlás egy szokásos hétvégi vásárlást hány százalékkal haladta meg. A következő 4a., 4b., és 4c. táblázatok a kutatás ez irányú adatait tartalmazzák, és azokat a legfontosabb élelmiszereket, illetve élelmiszer jellegű termékeket (pl. bor), amelyeket kutatásunk során az alkalmazott kérdéssor segítségével a vizsgálat tárgykörébe vontunk. 
A 4a. táblázat adatai azt mutatják, hogy legnagyobb mértékben (144 százalékkal) a liszt felvásárlása növekedett, de a baromfihúsból, tésztafélékből, tejből és cukorból is közel a dupla mennyiséget tették a vásárlók ezen a hétvégén kosarukba.

Az adatok azt is jelzik számunkra, hogy jelentősen többet vásároltunk azokból a termékekből is, amelyek szükségesek egy háztartásban vészhelyzet idején és raktározásuk is könnyen megvalósítható. Ide tartoznak többek között a főzéshez nélkülözhetetlen zsiradékok, a tartós élelmiszerek (szalámik, konzervek, a rizs és az ásványvizek) is.

Bár a táblázatban a tisztító- és fertőtlenítőszerek vásárlási adatait nem szerepeltettük, de mindenképpen szükséges megemlíteni azt, hogy e termékekből is jelentősen, átlagosan 125 százalékkal vásároltunk többet.

Legkevésbé az alkoholos termékekből képeztek a megkérdezettek tartalékot, valamint halból (persze ennek a terméknek a hosszú fagyasztása köztudottan nem szerencsés) és marhahúsból.

4a. TÁBLÁZAT

A vásárlások mennyisége 2020. március 13-15. hétvégéjén ( $\mathrm{N}=235)$

TABLE $4 a$ (Quantity of Products Bought during the Weekend of o3/13-15/2020)

\begin{tabular}{|c|c|c|c|c|}
\hline \multirow[t]{2}{*}{ Termékek (Products) } & \multicolumn{2}{|c|}{$\begin{array}{c}\text { Fogyasztás (a jelzett } \\
\text { mértékegységben) } \\
\text { (Consumption- in the unit } \\
\text { indicated) }\end{array}$} & \multicolumn{2}{|c|}{$\begin{array}{c}\text { Fogyasztás növekedése } \\
\text { (\%-ban) (Increase in } \\
\text { consumption }\end{array}$} \\
\hline & $\begin{array}{c}\text { Átlag } \\
\text { (Mean) }\end{array}$ & $\begin{array}{l}\text { Szórás (Std. } \\
\text { Deviation) }\end{array}$ & $\begin{array}{c}\text { Átlag } \\
\text { (Mean) }\end{array}$ & $\begin{array}{l}\text { Szórás (Std. } \\
\text { Deviation) }\end{array}$ \\
\hline Liszt (kg) (Flour) & 4,200 & 4,55 & 144,255 & 132,10 \\
\hline Baromfihús (kg) (Poultry meat) & 2,296 & 2,44 & 123,668 & 110,96 \\
\hline Tésztafélék (kg) (Pasta) & 1,837 & 1,72 & 123,213 & 120,41 \\
\hline Folyadéktej (liter) (Liquid milk) & 2,094 & 1,97 & 117,787 & 135,10 \\
\hline Cukor (kg) (Sugar) & 2,906 & 3,67 & 102,043 & 123,74 \\
\hline Olaj / zsír (kg) (Oil / fat) & 2,334 & 3,05 & 97,481 & 99,11 \\
\hline Rizs (kg) (Rice) & 2,094 & 3,57 & 96,855 & 97,52 \\
\hline Szalámik (kg) (Salamis) & 1,337 & 1,95 & 94,319 & 110,24 \\
\hline Ásványvizek (liter) (Mineral waters) & 6,396 & 9,23 & 90,175 & 115,22 \\
\hline Konzervek (doboz) (Canned food, can) & 2,306 & 3,85 & 89,809 & 116,35 \\
\hline Gyümölcsjoghurtok - pohár (Fruit yogurts - glass) & 2,745 & 2,67 & 78,149 & 94,75 \\
\hline Sertéshús (kg) (Pork) & 1,535 & 2,02 & 74,851 & 88,65 \\
\hline Bor (liter) (Wine) & 0,681 & 1,53 & 45,021 & 92,35 \\
\hline Hal (kg) (Fish) & 1,164 & 9,81 & 44,915 & 120,32 \\
\hline Sör (liter) (Beer) & 2,087 & 5,61 & 39,617 & 77,92 \\
\hline Marhahús (kg) (Beef) & 2,338 & 16,88 & 20,085 & 46,55 \\
\hline
\end{tabular}

Forrás (Source): Saját kutatás (Own research) N=235 
Huszka, P. - Huszka, P. B. - Lóre, V.

Vizsgáltuk a vásárlásnövekedést életkor szerinti bontásban is. A mintát ketté bontottuk 60 év alatti és 60 év feletti korcsoportra. A vizsgálat során a Mann-Whitney-féle nem paraméteres U-próbát használtuk fel.

Az elemzés eredményeként a 60 év feletti és 60 év alatti korosztályok tekintetében nincs szignifikáns eltérés a termékkategória szerinti felhalmozásban. A trendszerű eltéréseket a $4 b$. táblázat tartalmazza. Az adatok alapvetően abban különböznek a korábban bemutatottakhoz képest, hogy a hatvan év felettiek jellemzően nagyobb mennyiségeket vásároltak a korábban már felsorolt készítményekből.

4b. TÁBLÁZAT

TABLE $4 \boldsymbol{b}$

A vásárlás átlagos növekedése kor szerinti bontásban 2020 . március 13-15. hétvégéjén (Growth of Products Bought, Analysed by Age Groups during the Weekend of o3/13-15/2020)

\begin{tabular}{|c|c|c|c|c|}
\hline \multirow{2}{*}{ Termékek (Products) } & \multicolumn{2}{|c|}{$\begin{array}{c}60 \text { év alatti (Under the age } \\
\text { of } 60 \text { ) } N=193\end{array}$} & \multicolumn{2}{|c|}{$\begin{array}{c}60 \text { év feletti (Over the age } \\
\text { of } 60 \text { ) } N=37\end{array}$} \\
\hline & $\begin{array}{c}\text { Átlag } \\
\text { (Mean) }\end{array}$ & $\begin{array}{l}\text { Szórás (Std. } \\
\text { Deviation) }\end{array}$ & $\begin{array}{c}\text { Átlag } \\
\text { (Mean) }\end{array}$ & $\begin{array}{c}\text { Szórás (Std. } \\
\text { Deviation) }\end{array}$ \\
\hline Liszt (kg) (Flour) & 144,404 & 133,71 & 160,270 & 124,29 \\
\hline Baromfihús (kg) (Poultry meat) & 122,098 & 107,90 & 145,865 & 125,30 \\
\hline Tésztafélék (kg) (Pasta) & 126,373 & 122,75 & 119,324 & 110,00 \\
\hline Folyadéktej (liter) (Liquid milk) & 120,466 & 143,52 & 117,027 & 84,78 \\
\hline Cukor (kg) (Sugar) & 104,404 & 126,00 & 100,811 & 116,91 \\
\hline Olaj / zsír (kg) (Oil / fat) & 95,793 & 99,32 & 116,757 & 98,91 \\
\hline Rizs (kg) (Rice) & 99,870 & 98,93 & 91,514 & 92,21 \\
\hline Szalámik (kg) (Salamis) & 100,052 & 111,16 & 74,459 & 107,35 \\
\hline Ásványvizek (liter) (Mineral waters) & 88,088 & 112,00 & 113,243 & 132,98 \\
\hline Konzervek (doboz) (Canned food, can) & 91,218 & 118,19 & 94,595 & 111,05 \\
\hline Gyümölcsjoghurtok - pohár (Fruit yogurts - glass) & 79,145 & 95,46 & 83,514 & 94,20 \\
\hline Sertéshús (kg) (Pork) & 78,705 & 89,77 & 62,162 & 84,96 \\
\hline Bor (liter) (Wine) & 43,420 & 89,79 & 59,459 & 109,19 \\
\hline Hal (kg) (Fish) & 48,472 & 129,27 & 32,432 & 66,89 \\
\hline Sör (liter) (Beer) & 39,016 & 72,29 & 48,108 & 106,30 \\
\hline Marhahús (kg) (Beef) & 23,109 & 49,68 & 7,027 & 25,37 \\
\hline
\end{tabular}

Forrás (Source): Saját kutatás (Own research) $\mathrm{N}=230$

Vizsgáltuk a vásárlás növekedést nem szerinti bontásban is. A vizsgálat során a Mann-Whitney-féle nem paraméteres U-próbát használtuk fel. Az elemzés eredményeként a nők és a férfiak felhalmozási magatartásában nincs szignifikáns különbség, kivéve a gyümölcsjoghurtokat (Mann-Whitney
$\mathrm{U}=5243, \mathrm{p}=0,013)$, a fagyasztott zöldségeket (Mann-Whitney $\mathrm{U}=4928, \mathrm{p}=0,001$ ) és a rostos üdítőket (Mann-Whitney U=5017, p=0,002). A csak trendszerü és a szignifikáns eltéréseket a következő 4c. táblázat tartalmazza. 
A vásárlás változása termékcsoportonként nem szerinti bontásban 2020. március 13-15. hétvégéjén (Growth of Products Bought, Analysed by Gender during the Weekend of o3/13-15/2020)

\begin{tabular}{|c|c|c|c|c|}
\hline \multirow[b]{2}{*}{ Termékek (Products) } & \multicolumn{2}{|c|}{ Férfi (Male) N=105 } & \multicolumn{2}{|c|}{ Nő (Female) N=122 } \\
\hline & $\begin{array}{c}\text { Átlag } \\
\text { (Mean) }\end{array}$ & $\begin{array}{c}\text { Szórás (Std. } \\
\text { Deviation) }\end{array}$ & $\begin{array}{c}\text { Átlag } \\
\text { (Mean) }\end{array}$ & $\begin{array}{c}\text { Szórás (Std. } \\
\text { Deviation) }\end{array}$ \\
\hline Liszt (kg) (Flour) & 149,429 & 137,595 & 145,984 & 127,277 \\
\hline Tésztafélék (kg) (Pasta) & 123,286 & 129,204 & 128,770 & 113,373 \\
\hline Baromfihús (kg) (Poultry meat) & 128,286 & 124,356 & 123,295 & 96,713 \\
\hline Folyadéktej (liter) (Liquid milk) & 117,571 & 163,933 & 122,828 & 106,858 \\
\hline Cukor (kg) (Sugar) & 92,286 & 108,838 & 115,492 & $135,95^{8}$ \\
\hline Olaj / zsír (kg) (Oil / fat) & 95,524 & 103,124 & 103,918 & 96,635 \\
\hline Rizs (kg) (Rice) & 98,533 & 99,284 & 98,893 & 96,204 \\
\hline Szalámik (kg) (Salamis) & 103,000 & 131,086 & 90,984 & 90,491 \\
\hline Konzervek (doboz) (Canned food, can) & 83,190 & 120,677 & 100,574 & 114,186 \\
\hline Ásványvizek (liter) (Mineral waters) & 91,714 & 119,825 & 90,664 & 110,143 \\
\hline Gyümölcsjoghurtok - pohár (Fruit yogurts - glass) & 62,714 & 80,417 & 96,557 & 104,173 \\
\hline Sertéshús (kg) (Pork) & 77,333 & 96,606 & 76,803 & 82,697 \\
\hline Rostos üdítőital (Fibrous soft drink) & 52,524 & 94,846 & 91,369 & 115,072 \\
\hline Fagyasztott zöldségek (Frozen vegetables) & 46,571 & 72,984 & 83,770 & 92,525 \\
\hline Bor (liter) (Wine) & 51,619 & 108,061 & 41,475 & 79,134 \\
\hline Hal (kg) (Fish) & 49,476 & 159,502 & 43,115 & 77,247 \\
\hline Sör (liter) (Beer) & 46,952 & 82,650 & 35,902 & 75,534 \\
\hline Marhahús (kg) (Beef) & 20,000 & 50,283 & 21,475 & 44,604 \\
\hline
\end{tabular}

Forrás (Source): Saját kutatás (Own research) N=227

\section{Diszikusszió - Discussion}

A felmérés (és az irodalmi adatok) tükrében megállapítható, hogy a 2020 tavaszán hazánkban is megjelenő koronavírus-járvány pánikvásárlást okozott, és a választás szabadságát újra - a rendszerváltás éveit megelőző - fogyasztói kiszolgáltatottság váltotta fel.

A megkérdezettek véleménye és a szekunder adatok alapján megállapítható, hogy az élelmiszer-fogyasztást befolyásoló tényezők „rendszerelemzése” sem számol napjaink felhalmozási bevásárlásaival, ezért ezzel a modellt mindenképpen bővíteni szükséges. Megállapítható, hogy a válaszadók 60,4\%-a szerint érdemes felvásárolni. Az elemzés azt mutatja, hogy a 60 év felettiek 75 százaléka vélekedik így, míg a legfiatalabb korcsoport tagjai közül csak 62 százalék gondolja ezt.

A vizsgálat adatai azt mutatták, hogy legnagyobb mértékben (144 százalékkal) a liszt felvásárlása növekedett, de a baromfihúsból, tésztafélékből, tejből és cukorból is közel a dupla mennyiséget tették a vásárlók ezen a hétvégén kosarukba.

Az elemzés eredményeként a nók és a férfiak felhalmozási magatartásában nincs szignifikáns különbség, kivéve a gyümölcsjoghurtokat (Mann-Whitney U=5243, p=0,013), a fagyasztott zöldségeket (Mann-Whitney $\mathrm{U}=4928$, $\mathrm{p}=0,001$ és a rostos üdítóket (Mann-Whitney $\mathrm{U}=5017, \mathrm{p}=0,002)$. 


\section{5. ÖSSZEFOGLALÁs - SUMMARY}

Jelen publikáció megszületését napjaink eseményei generálták. A járványt övező vásárlási hullám ugyanis felkeltette érdeklődésünk - és jelen publikációban (egy feltáró publikáció keretében) néhány kérdés megválaszolását tűztük ki célul.

Az eredmények rávilágítanak arra is, hogy ebben az időszakban sokan tartalékkészleteket halmoztak fel a különböző termékekbőll. A legnagyobb mértékben a liszt felvásárlása növekedett, de például baromfihúsból és tésztafélékbőll is jelentősen többet vásároltak a megkérdezettek. A többnyire széles áruválasztékkal rendelkező nagyobb bolttípusok erre messzemenőkig alkalmasak voltak.

Az adatok azt is jelzik számunkra, hogy jelentősen többet vásároltunk azokból a termékekből is, amelyek szükségesek egy háztartásban vészhelyzet idején és raktározásuk is könnyen megvalósítható. Ide tartoznak többek között a főzéshez nélkülözhetetlen zsiradékok, a tartós élelmiszerek (szalámik, konzervek, a rizs és az ásványvizek) is.

\section{KöSZÖNETNYILVÁNÍTÁS -}

\section{ACKNOWLEDGEMENT}

A publikáció a Széchenyi István Egyetem által az EFOP 3.6.1-16-2016-00017 „Nemzetköziesítés, oktatói, kutatói és hallgatói utánpótlás megteremtése, a tudás és technológiai transzfer fejlesztése, mint az intelligens szakosodás eszközei a Széchenyi István Egyetemen” című uniós projekt keretében készült.

\section{IRODALOMJEGYZÉK - REFERENCES}

Belák, S. - Tuboly, S. - Varga, J.: Állatorvosi mikrobiológia. Mezőgazdasági Kiadó, Budapest, 1983.

Forbes: Vásárlási láz: 57 milliárd forintot hagytak a szupermarketekben a magyarok alig egy hét alatt. 2020. https://forbes. hu/uzlet/vasarlasi-laz-57-milliardforintot-hagytak-a-szupermarketekbena-magyarok-alig-egy-het-alatt/ (Letöltés dátuma: 2020.03.23.)
Harris, D. M. - Guten, S: Health protecting behaviour. an exploratory study. Journal of Health and Social Behaviour. 1979. 20 17-29.

Huszka, P.: Divat a korai dohányzás? - avagy dohányzási szokások vizsgálata a 12-16 évesek körében. Egészségfejlesztés. 2012. $53(4)$ 9-15.

Huszka,P.:Amodernmarketingmenedzsment ismerettára. Universitas-Győr Nonprofit Kft., Győr, 2015.

Index: 275 százalékkal több löncshús fogyott múlt héten. 2020. https://index.hu/ gazdasag/2020/03/26/koronavirus_ kiskereskedelem_fmcg_nielsen/ (Letöltés dátuma: 2020.03.23.)

Infostart: Szétszaladhat a világban az új koronavírus, azonnal léptek a hatóságok. 2020. https://infostart.hu/ kulfold/2020/01/23/szetszaladhat-avilagban-az-uj-koronavirus-azonnalleptek-a-hatosagok (Letöltés dátuma: 2020.03.24.)

Kományi, É.: Életvédelem II., A biztonságos és egészséges élettevékenység alapjai. Főiskolai jegyzet. II. Rákóczi Ferenc Kárpátaljai Magyar Főiskola, 2014. http://genius-ja.uz.ua/sites/default/ files/csatolmanyok/soos-kalmanosztondijprogram-jegyzettamogatasipalyazat-nyertesei 546/abiztonsagoses egeszsegeselettevekenysegalapjai.pdf (Letöltés dátuma: 2020.04.15.)

Kotler, P. - Keller, K. L.: Marketingmenedzsment. Akadémiai Kiadó, Budapest, 2012.

KSH: Gyorstájékoztató, Kiskereskedelem (2020 február). 2020a. http://www.ksh. hu/docs/hun/xftp/gyor/kis/kis2002.html (Leöltés dátuma: 2020.04.14.)

KSH: Heti Monitor. 2020b. https://www. ksh.hu/heti-monitor/index.html (Leöltés dátuma: 2020.06.09.)

KSTA: Corona-Epidemie Exp erten: „Virus wird Einkaufsgewohnheiten dauerhaft ändern”. 2020. https://www.ksta.de/ wirtschaft/corona-epidemie-experten--virus-wird-einkaufsgewohnheitendauerhaft-aendern-36428198 (Letöltés dátuma: 2020.04.25.)

Lehota, J.: Élelmiszer-gazdasági marketing. Műszaki Kiadó, Budapest, 2001. 
Mai Piac: Nem fogy elég. Mai Piac. 2000. 7 (6) $64-65$.

Perez, S.: Grocery delivery apps see record downloads amid coronavirus outbreak. 2020. https://techcrunch. com/2020/03/16/grocery-delivery-appssee-record-downloads-amid-coronavirusoutbreak (Leöltés dátuma: 2020.04.14.)

Pénzcentrum: Ezértmenekülneka vásárlásba a koronavírustól pánikoló magyarok. 2020. https://www.penzcentrum. hu/otthon / ezert-menekulnek-avasarlasba-a-koronavirustol-panikolomagyarok.1089629.html

(Letöltés dátuma: 2020.04.14.)

Shaw, A.: Covid 19 coronavirus: By the numbers - What Kiwis have been panic buying. 2020. https://www.nzherald. co.nz/business/news/article.cfm?c $\mathrm{id}=3$ \&objectid $=12319948 \quad$ (Letöltés dátuma: 2020.04.26.)

Sokszínúvidék: Felvásárlási láz külföldön: sláger a vécépapír, a vörösbor és a kölni is. 2020. https://sokszinuvidek.24. $\mathrm{hu} / \mathrm{mozaik} / 2020 / 03 / 24 /$ koronavirushianycikkek-nemetorszag-franciaorszagvecepapir-vorosbor-hollandia/ (Letöltés dátuma: 2020.03.24.)
Stuttgarter-Zeitung:

Einkaufsgewohnheiten

Supermarktchef: www.stuttgarter-zeitung.de/inhalt. corona-krise-im-raum-stuttgartsupermarktchef-einkaufsgewohnheitenwerden-sich-veraendern.714dd2a7-4a614d9f-97af-165b8ab5cdc8.html (Letöltés dátuma: 2020.04.25.)

Trendfm: Bejelentkezés a karanténnal sújtott Olaszországból. 2020. https://trendfm. hu/cimlap/bejelentkezes-a-karantennalsujtott-olaszorszagbol-13505 (Letöltés dátuma: 2020.03.24.)

Worldometers: Élelem. 2020a. www. worldometers.info/hu/ (Leöltés ideje: 2020. 04. 10.)

Worldometers: Coronavirus. 2020b.https:// www.worldometers.info/coronavirus/ (Letöltés dátuma: 2020.04.14.)

Worldometers: Coronavirus. 2020c. https:// www.worldometers.info/coronavirus/ (Letöltés dátuma: 2020.06.10.)

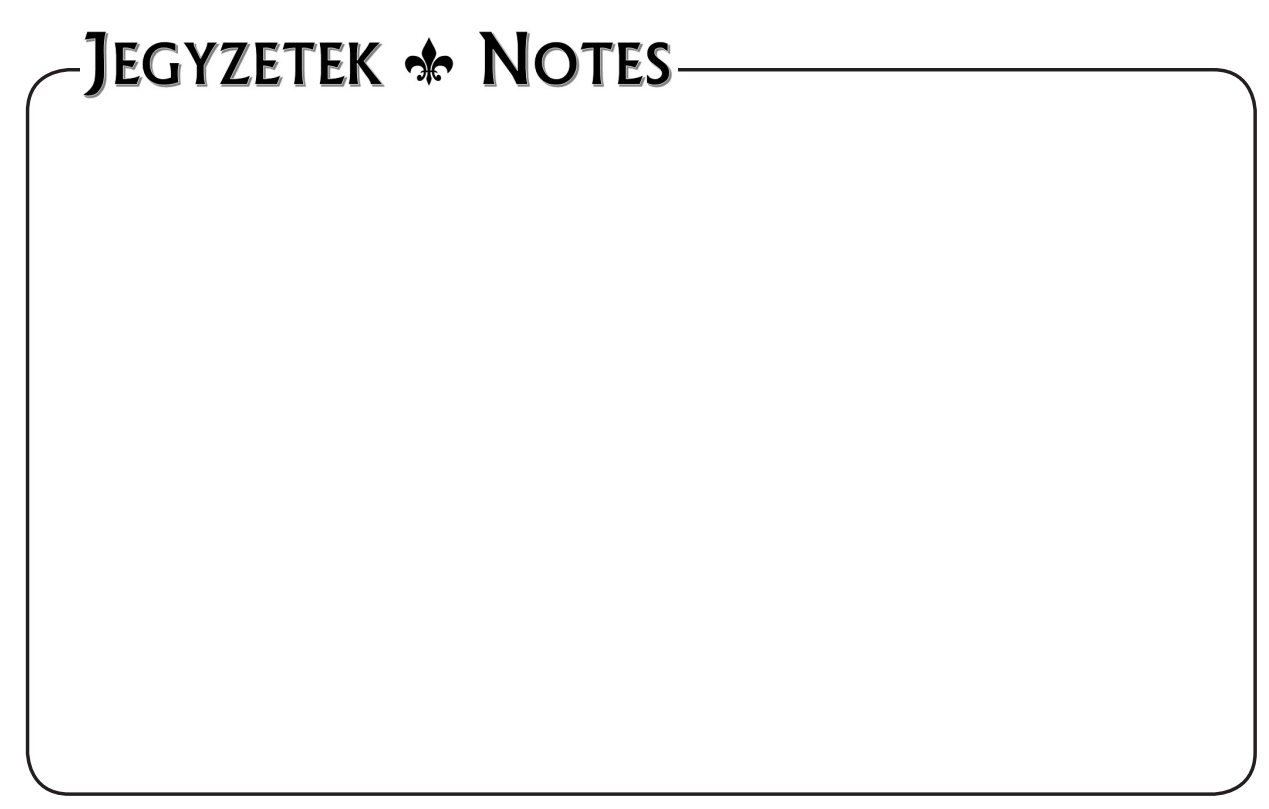

